\title{
Kewenangan Pemerintah Daerah dalam Penataan Ruang Setelah Berlakunya Undang-Undang Nomor 23 Tahun 2014
}

\author{
Ari Dahfid \\ Lembaga Penjamin Mutu Pendidikan (LPMP), Nusa Tenggara Barat \\ ad86malingi@gmail.com \\ Submitted: 2017-09-27; Reviewed: 2017-10-18; Accepted: 2017-11-07
}

\begin{abstract}
Implementation of the Law No. 23 of 2014 concerning Local Government gave a change against separation of spatial planning and the implication to local policy. The purpose of this research is to know the regulation of spatial planning in Mataram City before and after the implementation of law concerning local government by multi perspective especially about authority of government as well as knowing how the harmonization and synchronization local regulation of Spatial Planning in Mataram City with law concerning local government. This research used empiric-normative method, studying about regulation and seeing how the regulation can be implemented in the society. The result of this research showed that Mataram City local government in regulating about spatial planning, before and after the implementation of Law concerning local government, still referred to Local Regulation No. 12 of 2012 concerning Spatial Planning (Revised). This thing showed that the activity of spatial planning in Mataram City just referred to the local regulation No. 12 of 2011, both in the authority and things that related. There were disharmony in several article in local regulation concerning spatial planning of Mataram City with Law concerning Local Government, such as in article 11 subsection 2 point 5 Regulation of Spatial Planning Mataram City and article 14 subsection (1), article 27 subsection (1)and (2), article 28, and article 29 related with authority of marine resource management.
\end{abstract}

Keywords: Authority; Local Government; Spatial Planning

\section{PENDAHULUAN}

Tujuan pemerintahan Negara Indonesia pada umumnya terdapat dalam pembukaan UUD 1945 setelah amandemen. adalah melindungi segenap bangsa Indonesia dan untuk memajukan kesejahteraan umum, mencerdaskan kehidupan bangsa, serta ikut melaksanakan ketertiban dunia yang berdasarkan kemerdekaan, perdamaian abadi dan keadilan sosial ${ }^{1}$.

1 Sahrul Haidin, "Pelaksanaan Pengelolaan Keuangan Desa Setelah Berlakunya Undang-Undang Nomor 6 Tahun 2014 Tentang Desa (Studi Di Kabupaten Dompu)", Jumal IUS, Vol V Nomor I, April 2017, hlm 144 
Pemberlakuan Undang-Undang Nomor 23 Tahun 2014 tentang Pemerintahan Daerah (selanjutnya ditulis UU Pemda) terhadap penyelenggaraan penataan ruang, urusan pemerintahan merupakan kewenangan Presiden yang pelaksanaannya dapat didelegasikan kepada Menteri yang membidangi urusan tertentu bidang pemerintahan, serta Kepala Daerah sebagai Wakil Pemerintah Pusat di Daerah. Diberlakukannya UU Pemda memberikan perubahan terhadap pembagian kewenangan penyelenggaraan penataan ruang dan berimplikasi terhadap implementasi kebijakan sektoral di daerah.

Sebagai contoh, urusan pengelolaan ruang laut sampai dengan 4 (empat) mil laut diukur dari garis pantai ke arah laut lepas dan/atau ke arah perairan kepulauan yang sebelumnya menjadi kewenangan kabupaten/kota menjadi kewenangan provinsi sehingga berimplikasi terhadap kewenangan penyusunan dan penetapan Rencana Zonasi Wilayah Pesisir dan Pulaupulau Kecil (RZWP3-K) Kabupaten/Kota. Menyikapi hal tersebut, Kementerian Kelautan dan Perikanan tengah menyusun Surat Edaran (SE) Menteri Kelautan dan Perikanan tentang Pembagian Sub Urusan Kelautan Pesisir dan Pulau-pulau Kecil bagi Gubernur dan Bupati/Walikota.

Implikasi dari pemberlakuan UU Pemda terhadap penyelenggaraan penataan ruang lainnya adalah proses evaluasi Rancangan Perda Rencana Tata Ruang Provinsi/Kabupaten/Kota yang menjadi lebih panjang karena dalam proses evaluasi, Menteri Dalam Negeri harus berkoordinasi dengan Menteri Agraria dan Tata Ruang. Disamping itu, Rancangan

${ }^{2}$ Arya Sosman, "Kajian Terhadap Perlindungan Dan Pengelolaan Lingkungan Hidup Dalam Tata Ruang
Perda Rencana Tata Ruang Kabupaten/Kota yang sebelumnya cukup dievaluasi oleh Gubernur, harus dikonsultasikan dengan Menteri Dalam Negeri. Hal ini perlu ditindak lanjuti dengan penyesuaian terhadap Permendagri Nomor 28 Tahun 2008 tentang Tata Cara Evaluasi Rancangan Peraturan Daerah Tentang Rencana Tata Ruang Daerah. Selain itu, pemberlakuan UU Pemda juga memunculkan kewenangan baru bagi Pemerintah Pusat untuk menyusun Rencana Detail Tata Ruang (RDTR) di Kawasan Perbatasan di kota Mataram.

Berkaitan dengan penataan ruang wilayah kota, Pasal 26 UU Penataan Ruang secara khusus mengamanatkan perlunya penyediaan dan pemanfaatan ruang terbuka hijau, yang proporsi luasannya ditetapkan paling sedikit 30 (tiga puluh) persen dari luas wilayah kota, yang diisi oleh tanaman, baik yang tumbuh secara alamiah maupun yang sengaja ditanam. Perda RTRW Kota Mataram, di samping memuat secara khusus pengaturan RTH tetapi juga mengatur berbagai aspek tata ruang yang tersebar di berbagai pasal di di dalam Perda tersebut, Peraturan Daerah Nomor 12 Tahun 2011 tentang Rencana Tata Ruang Wilayah Kota Mataram sebagai ujung tombak dalam implementasi penataan ruang yang secara teoritis harus terdapat sinkronisasi dengan kedua Undang-undang tersebut di atas."

\section{PEMBAHASAN}

\section{Pengaturan Tata Ruang Di Kota Mataram Sebelum Dan Sesudah Berlakunya Undang-Undang No 23 Tahun 2014 Tentang Pemerintahan}

Kota Mataram", Jurnal IUS Vol II Nomor 5 Agustus 2014, hlm. 350. 


\section{Daerah}

Bahwa berdasarkan UU Penataan Ruang, Peraturan Pemerintah Nomor 26 Tahun 2008 tentang Rencana Tata Ruang Wilayah Nasional, dan Peraturan Daerah Provinsi Nusa Tenggara Barat Nomor 3 Tahun 2010 tentang Rencana Tata Ruang Wilayah Provinsi Nusa Tenggara Barat, maka kebijakan, strategi dan arahan pemanfaatan ruang wilayah dimaksud perlu dijabarkan ke dalam Rencana Tata Ruang Wilayah Kota Mataram dengan tujuan bahwa : a) untuk melaksanakan pembangunan wilayah Kota Mataram secara terpadu, lestari, optimal, seimbang dan serasi, sesuai dengan karakteristik, fungsi, dan predikatnya; b) diperlukan dasar untuk pedoman perencanaan, pemanfaatan, dan pengendalian ruang di wilayah Kota Mataram.

Bahwa berdasarkan pertimbangan sebagaimana dimaksud pada huruf a dan huruf $b$ perlu dibentuk Peraturan Daerah tentang Rencana Tata Ruang Wilayah Kota MataramTahun 2011-2031, yang berdasar pada UUD NRI 1945 dan beberapa undang-undang lainnya, yakni :

a. Pasal 18 ayat (6) Undang-Undang Dasar Negara Republik Indonesia Tahun 1945 perubahan keempat;

b. Undang-Undang Nomor 64 Tahun 1958 tentang Pembentukan Daerahdaerah Tingkat I Bali, Nusa Tenggara Barat dan Nusa Tenggara Timur (Lembaran Negara Republik Indonesia Tahun 1958 Nomor 115, Tambahan Lembaran Negara Republik Indonesia Nomor 1649);

c. Undang-Undang Nomor 5 Tahun 1960 tentang Peraturan Dasar Pokokpokok Agraria (Lembaran Negara Republik Indonesia Tahun 1960
Nomor 104, Tambahan Lembaran Negara Republik Indonesia Nomor 2013);

d. Undang-Undang Nomor 8 Tahun 1981 tentang Hukum Acara Pidana (Lembaran Negara Republik Indonesia Tahun 1981 Nomor 76, Tambahan Lembaran Negara Republik Indonesia Nomor 3209);

e. Undang-Undang Nomor 5 Tahun 1984 tentang Perindustrian (Lembaran Negara Republik Indonesia Tahun 1984 Nomor 22, Tambahan Lembaran Negara Republik Indonesia Nomor 3274);

f. Undang-Undang Nomor 5 Tahun 1990 tentang Konservasi Sumber Daya Alam Hayati dan Ekosistemnya (Lembaran Negara Republik Indonesia Tahun 1990 Nomor 49, Tambahan Lembaran Negara Republik Indonesia Nomor 3419);

g. Undang-Undang Nomor 4 Tahun 1992 tentang Permukiman dan Perumahan (Lembaran Negara Republik Indonesia Tahun 1992 Nomor 11, Tambahan Lembaran Negara Republik Indonesia Nomor 3469).

h. Undang-Undang Nomor 26 Tahun 2007 tentang Penataan Ruang (Lembaran Negara Republik Indonesia Tahun 2007 No 68);

i. Undang-Undang No 32 Tahun 2004 dan telah diubah dengan UndangUndang No 23 Tahun 2014 Tentang Pemerintahan Daerah (Lembaran Negara Republik Indonesia Tahun 2014 No 244).

Pemerintah Kota Mataram sampai dengan munculnya UU No. 23 Tahun 2014 
tentang Pemerintahan Daerah (UU Pemda), dibidang penataan ruang masih menggunakan payung hukum Peraturan Daerah No. 12 Tahun 2011 tentang Rencana Tata Ruang wilayah Kota Mataram (Perda RTRW Kota Mataram), hal ini dikarenakan antara lain perlu adanya kajian yang mendalam terkait dengan pelaksanaan tata ruang sebelum dan sesudah berlakunya UU Pemda, sehingga nantinya menghasilkan perda yang selaras dengan kebijakan pemerintah provinsi maupun pemerintah pusat.

Sejak lahirnya UU Pemda sampai dengan awal April 2017 terdapat banyak pelanggaran tata ruang yang terkesan dibiarkan oleh pemerintah Kota Mataram, seperti contoh pembangunan Rumah Makan Cepat Saji KFC dan Rumah Makan Al Mahera di Jalan Langko yang merupakan Zona Merah untuk kawasan perdagangan. Pendiri Kota Mataram, HL. Mudjitahid dalam sebuah kesempatan menyayangkan bergesernya tata ruang Kota Mataram. Hal ini dipicu oleh perencanaan yang tidak matang dibuat oleh Pemerintah Kota Mataram. ${ }^{3}$ Pelanggaranpelanggaran yang terjadi mengindikasikan bahwa Pemerintah kota Mataram tidak melaksanakan Perda Kota Mataram tentang RTRW (Rencana Tata Ruang Wilayah). Dengan banyaknya fenomena pelanggaran tata ruang ditambah dengan ketidaktegasan pemerintah, penataan ke depan menjadi semakin berat.

Ditengah munculnya berbagai pelanggaran tata ruang serta adanya tuntutan beberapa elemen masyarakat agar Perda RT / RW Kota Mataram segera menyesuaiakan dengan perubahan yang ada termasuk di dalamnya UU Pemda, maka pada tanggal 22 April 2017 DPRD Kota Mataram bersama dengan Pemerintah Kota Mataram menetapkan Perda RTRW Kota Mataram Tahun 2011-2031 yang merupakan revisi Perda No. 12 Tahun 2011 tentang RT / RW Kota Mataram.Perubahan Perda RT / RW Kota Mataram dihajatkan untuk memenuhi secara normatif berbagai ketentuan peraturan perundang-undangan termasuk di dalamnya adalah UU Pemda (UU No. 23 Tahun 2014) dan penyelarasan dengan berbagai program strategis nasional yang tertuang di dalam RPJMN 2015-2019, serta dalam rangka melakukan pembinaan penataan ruang di daerah yaitu untuk meningkatkan kualitas, efektifitas, peran masyarakat, serta meningkatkan kapasitas dan kemandirian pemangku kepentingan dalam penyelenggaraan penataan ruang, sehingga penekanan revisi RT / RW tersebut lebih bersifat HOLISTIKFUTURISTIK yaitu lebih mengedepankan perubahan secara menyeluruh mencakup semua sistem perkembangan pembangunan daerah dan memiliki arah kebijakan dengan jangkauan jauh ke depan yaitu sampai dengan tahun 2031.

Dari uraian yang dikemukakan dari awal (huruf a dan huruf b) dapat ditarik beberapa kesimpulan terkait dengan penataan ruang di Kota Mataram, yakni :

a. Pengaturan tata ruang di Kota Mataram baik sebelum dan sesudah berlakunya UU No. 23 Tahun 2014 tentang Pemerintahan Daerah (UU Pemda) yakni mengacu pada Peraturan Daerah No. 12 Tahun 2011 tentang Rencana Tata Ruang Wilayah Kota Mataram (Perda RT /

\footnotetext{
${ }^{3}$ Lomboknice.blogspot.co.id, Penyimpangan Tata Ruang Di Mataram Diduga Sangat Parah, 2014
} 
$\mathrm{RW}$;

b. Dalam hal penggunaan lahan, rentang waktu antara tahun 20112013 penggunaan lahan kota Mataram cukup banyak untuk sektor Pendidikan, perumahan, perkantoran dan pertokoan sedangkan di rentang tahun 2013 sampai dengan saat ini penggunanaan lahan di kota mataram lebih menitikberatkan pada sektor pelayanan dasar masyarakat, seperti pendidikan dan kesehatan serta merevitalisasi pasar dan pusat perdagangan ke lahan baru serta membangun pusat perbelanjaan baru;

c. Dalam hal kewenangan, kewenangan yang dimiliki dan diterapkan oleh pemerintah kota Mataram terhadap penataan ruang adalah sesuai dengan rambu-rambu yang ada pada Perda RTRW, namun tidak jarang kebijakan yang diambil pemerintah terkadang berbenturan dengan adat istiadat dan persoalan lain yang sudah menjadi tradisi dalam kehidupan bermasyarakat;

d. Dalam hal pelanggaran terhadap aturan tata ruang, sejak Perda RTRW diberlakukan untuk mengkawal pelaksanaan tata ruang di kota mataram, sangat banyak ditemukan pelanggaranpelanggaran yang terjadi dan terkesan dibiarkan oleh pemerintah. Hal ini menyebabkan tata ruang kota mataram menjadi kurang

\footnotetext{
4 AA.Oka Mahendra, "Harmonisasi Peraturan Perundang-undangan", http://www. djpp.depkumham.go.id/htn-dan-puu/421-
}

aman, nyaman dan ramah bagi warga masyarakat;

e. Sebagai bagian komitmen Pemerintah Kota Mataram terhadap Penataan ruang yang nyaman, produktif dan berkelanjutan serta sebagai upaya menghindari terjadinya tumpang tindih aturan antara Perda RTRW Kota Mataram dengan UU Pemda, DPRD Kota Mataram bersama Pemerintah Kota Mataram menetapkan Perda RTRW Kota Mataram Tahun 20112031(Perda Revisi).

\section{Sinkronisasi Antara Perda RTRW Kota Mataram Dengan Undang-Undang No 23 Tahun 2014 Tentang Pemerintahan Daerah}

Secara umum, prosedur sinkronisasi diawali dengan inventarisasi, yaitu suatu kegiatan untuk mengetahui dan memperoleh data dan informasi tentang peraturan perundang-undangan terkait. Selanjutnya dilakukan analisa terhadap substansi. Menurut Oka Mahendra ${ }^{4}$, Harmonisasi idealnya dilakukan pada saat perancangan peraturan perundangundangan. Pengharmonisasian rancangan undang-undang mencakup 2 (dua) aspek sebagai berikut:

1. Pengharmonisasian materi muatan rancangan undang-undang dengan:
a. Pancasila;
b. Undang-Undang Dasar Negara Republik Indonesia Tahun 1945/harmonisasi vertikal;
c. Undang-undang/harmonisasi

harmonisasi-peraturan-perundang-undangan.html diakses tanggal 27 Maret 2017, hlm 2 
horizontal;

d. Asas-asas peraturan perundangundangan:

1) Asas pembentukan.

2) Asas materi muatan.

3) Asas-asas lain yang sesuai dengan bidang hukum rancangan undang-undang yang bersangkutan.

2. Pengharmonisasian rancangan undang-undang dengan teknik penyusunan peraturan perundangundangan yang meliputi:
a. Kerangka peraturan perundang- undangan;
b. Hal-hal khusus;
c. Ragam bahasa;
d. Bentuk rancangan peraturan perundang-undang.

Pengharmonisasian dilakukan dengan cara sebagai berikut: ${ }^{5}$

1. Pastikan bahwa rancangan undangundang mencantumkan nilai-nilai filosofis Pancasila dan pasal-pasal rancangan undang-undang yang bersangkutan tidak bertentangan dengan nilai-nilai tersebut;

2. Pastikan bahwa pasal-pasal Undang-Undang Dasar Negara Republik Indonesia Tahun 1945 yang memerintahkan pembentukannya telah dicantumkan dengan benar dan pastikan pula bahwa rancangan undang-undang telah selaras dengan prinsip-prinsip penyelenggaraan negara menurut Undang-Undang Dasar;

3. Gunakan istilah hukum atau pengertian hukum secara konsisten;
4. Teliti dengan seksama apakah materi muatan rancangan undangundang telah serasi/selaras dengan undang-undang lain terkait;

5. Pastikan bahwa asas-asas peraturan perundang-undangan baik asas pembentukan, asas materi muatan, maupun asas lain yang berkaitan dengan bidang hukum yang diatur dalam rancangan undang-undang, telah terakomodasikan dengan baik dalam rancangan undang-undang;

6. Pastikan bahwa pedoman teknik penyusunan peraturan perundangundangan telah dipatuhi secara konsisten;

7. Pastikan bahwa bahasa yang digunakan dalam merumuskan norma dalam rancangan undangundang telah sesuai dengan kaidah bahasa indonesia yang baik dan benar serta mengunakan pilihan kata yang tepat, jelas dan pasti.

Pengharmonisasian rancangan undangundang yang dilaksanakan secara cermat dan profesional akan menghasilkan rancangan undang-undang yang memenuhi syarat sebagai rancangan undang-undang yang baik.

Ada 8 (delapan) kriteria hukum yang baik menurut Lon Fuller ${ }^{\mathbf{6}}$ sebagai berikut:

1. Hukum harus dituruti semua orang, termasuk oleh penguasa negara;

2. Hukum harus dipublikasikan;

3. Hukum harus berlaku ke depan, bukan berlaku surut;

4. Kaidah hukum harus ditulis secara jelas, sehingga dapat diketahui dan diterapkan secara benar;

5. Hukum harus menghindari diri dari 
kontradiksi-kontradiksi;

6. Hukum jangan mewajibkan sesuatu yang tidak mungkin dipenuhi;

7. Hukum harus bersifat konstan sehingga ada kepastian hukum. Tetapi hukum harus juga diubah jika situasi politik dan sosial telah berubah;

8. Tindakan para aparat pemerintah dan penegak hukum haruslah konsisten dengan hukum yang berlaku.

Berdasarkan Undang-undang Nomor 26 Tahun 2007 tentang Penataan Ruang khususnya pada Pasal 8, 9, 10 dan 11 mengamanatkan bahwa penyelenggaraan penataan ruang (pengaturan, pembinaan, pengawasan, terhadap pelaksanaan penataan ruang (perencanaan, pemanfaatan dan pengendalian pemanfaatan ruang) dilakukan oleh Pemerintah dan Pemerintah Daerah. Oleh karena itu, penataan ruang menjadi wadah bagi kegiatan pembangunan yang memanfaatkan ruang, sehingga penataan ruang dapat menjadi acuan dan pedoman bagi perumusan kebijakan pembangunan sektoral, regional dan daerah.

Akan tetapi, diakui atau tidak sebagaian besar pembangunan kota di Indonesia kurang mengandalkan perencanaan tata ruang yang baik. Bahkan, hebatnya jika pun sudah ada tata ruang, aparat tidak segan-segan melakukan pembangkangan dengan melakukan pembiaran atas pelanggaran terhadap tata ruang yang ada.Terlalu banyak contoh tata ruang dikembangkan untuk daerah resapan, daerah hijau, atau pun daerah hunian

7 Guritno Soejodibroto, Makalah: Tata Ruang Dalam Pembangunan Kota Yang Berkelanjutan, "namun" dikembangkan menjadi daerahdaerah komersial dengan bangunan diatasnya. $^{7}$

Hal ini kemudian bertolak dengan UUPPLH yang menyatakan bahwa pemerintah berkewajiban untuk melakukan perlindungan dan pengelolaan lingkungan hidup dalam Pelaksanaan Pembangunan berkelanjutan agar lingkungan hidup Indonesia dapat tetap menjadi sumber dan penunjang hidup bagi rakyat Indonesia serta makhluk hidup lain, sebagaimana disebutkan di atas mengenai tata urutan peraturan perundang-undangan yang dari urutan tertinggi sampai terendah yakni mulai dari UUD NRI 1945, TAP MPR, Undang-Undang/Perpu, Peraturan Pemeritah, Peraturan Presiden, dan Peraturan Daerah, menunjukkan adanya hierarki atau teori berjenjang.

Secara hierarki, kedudukan RT / RW Kota menjadi ujung tombak (sebelum RDTR) dari peraturan Penataan Ruang, sebab dalam pembuatan RT / RW Kota / Kabupaten harus berpedoman kepada RT / RW Provinsi, sedangkan RT / RW Provinsi harus berpedoman pada UU Penataan Ruang. Pemerintah Pusat memiliki wewenang dalam pengaturan, pembinaan, dan pengawasan terhadap pelaksanaan penataan ruang wilayah nasional, provinsi, dan kabupaten/kota, serta terhadap pelaksanaan penataan ruang kawasan strategis nasional, provinsi, dan kabupaten/ kota. Demikian juga dengan Pemerintah Provinsimeliputipengaturan, pembinaan, dan pengawasan terhadap pelaksanaan penataan ruang wilayah provinsi, dan kabupaten/kota, serta terhadap pelaksanaan penataan ruang kawasan strategis provinsi

Jakarta: Asosiasi DPRD Kota Seluruh Indonesia, 2009, hlm. 5 
dan kabupaten/kota.Kedudukan RTRW

Kota dalam sistem penataan ruang dan sistem perencanaan pembangunan nasional dapat dilihat dalam diagram di bawah ini ${ }^{8}$ :

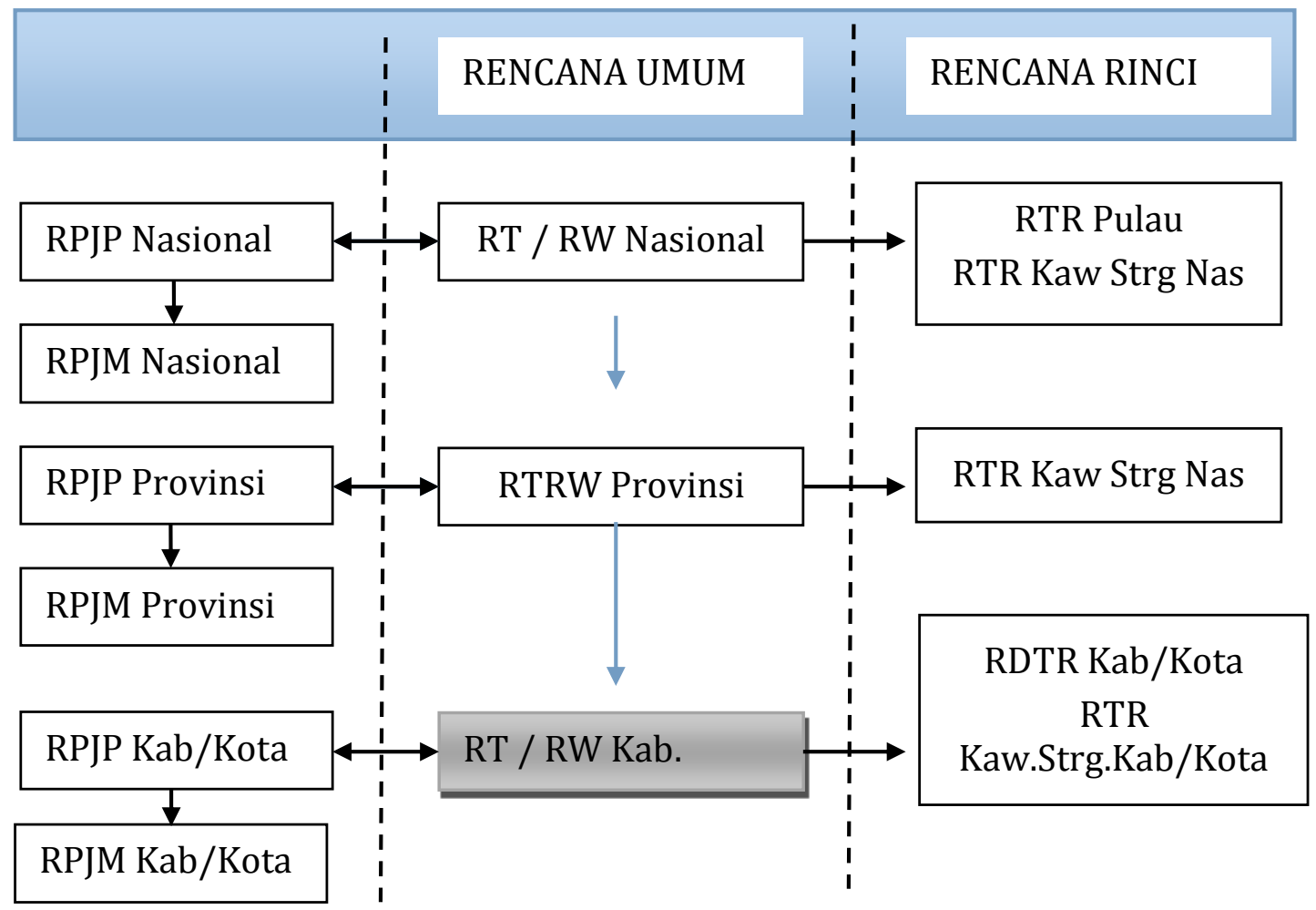

\section{Kedudukan RT / RW Kota Dalam Sistem Penataan Ruang Dan Sistem Perencanaan Pembangunan Nasional}

Pembentukan peraturan daerah berjalan dengan baik. Sesuai ketentuan mengalami peningkatan pesat sejak Pasal 251 ayat (2) UU Nomor 23 tahun desentralisasi diberlakukan dengan UU No.22 Tahun 1999 yang kemudian digantikan dengan UU No.32 Tahun 2004 dan kemudian diubah lagi dengan UU No. 23 Tahun 2014. Namun diperoleh gambaran umum perda-perda yang telah dibentuk dipertanyakan dari segi kualitas. Pembatalan perda menunjukkan gejala bahwa proses harmonisasi peraturan pusat dengan peraturan daerah yang tidak

${ }^{8}$ Departemen Pekerjaan Umum, Pedoman Bahan Konstruksi Bangunan dan Rekayasa Sipil, 2014 (UU Pemda) yang menegaskan bahwa perda kabupaten/kota dan peraturan bupati/walikota yang bertentangan dengan ketentuan peraturan perundang-undangan yang lebih tinggi, kepentingan umum, dan/atau kesusilaan dibatalkan oleh gubernur sebagai wakil pemerintah pusat. Hingga kini berdasarkan data dari Kementerian Dalam Negeri telah tercatat sebanyak 1983 yang dibatalkan dan masih

Penyusunan Rencana Tata Ruang Wilayah Kota, Jakarta, 2009, hlm 5 
terdapat ribuan Perda yang direkomendasikan untuk dievaluasi dan/atau dibatalkan. Perda yang dibatalkan pada umumnya Perda tentang pajak dan retribusi daerah. Sampai dengan bulan Juli 2009 peraturan daerah tentang pajak dan retribusi daerah dibatalkan sudah mencapai 1152 Perda. Sebelum berlakunya UU Pemda sudah terdapat sekitar 8.000 perda tentang pajak dan retribusi daerah yang dibuat dan lebih dari 3000 perda tersebut terindikasi bermasalah. Perda-perda yang mengatur pajak dan restribusi dan bermacam-macam pungutan lainnya dibatalkan karena pada umumnya bertentangan dengan peraturan perundangundangan yang lebih tinggi dan dinilai telah yang menimbulkan biaya ekonomi tinggi dan menghambat iklim investasi.

Namun demikian jika dicermati kemungkinan besar dalam setiap pembentukan perda bermasalah terdapat satu atau lebih persoalan sebagai berikut:

1. Daerah menganggap dengan tidak adanya kerangka acuan yang jelas dalam membentuk Perda maka pembentukan Perda mengabaikan ketentuan-ketentuan prinsip mengenai asas dan materi muatan Pembentukan Perda sebagaimana ditetapkan UU No.10/2004 dan UU No.23 Tahun 2014;

2. Daerah memahami prinsip-prinsip pengaturan penyusunan Perda sesuai UU No.10/2004 dan UU No.23/2014 namun kurang kapasitas pengetahuan dan pengalaman dalam melakukan teknik-teknik perumusan norma yang dinilai tidak bertentangan dengan peraturan perundang- undangan;

3. Kurangnya pemahaman dikalangan penyusun perda mengenai teknik penyusunan peraturan daerah yang antara lain disebabkan oleh kurangnya pengalaman penyusun perda mengenai ilmu pengetahuan perundang-undangan dan teknik penyusunan perda sesuai ketentuan peraturan perundang-undangan;

4. Langkah-langkah pembinaan yang dilakukan oleh instansi Pusat kepada aparatur pemerintah daerah dalam penyusunan Perda kemungkinan belum optimal dan belum merata;

5. Belum adanya kerangka acuan yang jelas bagi daerah mengenai tata laksana harmonisasi Raperda sebagai salah satu instrumen penting dalam rangka menjaga harmonisasi Perda dengan PUU. Perpres tentang Tata Cara Mempersiapkan Perda hingga kini belum ditetapkan;

6. Bentuk-bentuk hubungan komunikasi, konsultasi, klarifikasi Raperda antara instansi Pemerintah dengan aparat terkait di daerah yang selama ini diterapkan kemungkinan kurang efektif;

7. Peran Gubernur dalam membina dan mengawasi penyelenggaraan pemerintahan kabupatan/kota kemungkinan belum optimal.

Disamping hal-hal tersebut di atas, perlu cermati berbagai persoalan yang kemungkinan bersumber dari sisi Pemerintah yang mempersulit Pemda dalam menyusun Perda, antara lain:

1. PUU yang menjadi landasan atau 
pedoman Perda dalam menyusun Perda mengalami perubahan atau pergantian yang cepat dan daerah kurang siap menyikapi perubahan tersebut;

2. PUU menjadi landasan atau pedoman bagi daerah dalam menyusunan Perda terlambat diterbitkan;

3. Secara teknis, lingkup PUU yang harus diharmonisasi oleh daerah banyak dan beragam mulai dari UU sampai dengan Peraturan Menteri, sehingga proses harmonisasi Raperda membutuhkan waktu dan energi yang lebih banyak;

4. Inkonsistensi peraturan perundangundangan di tingkat Pusat dapat berdampak terjadinya kekeliruan daerah dalam menentukan ketentuan acuan hukum. Hal ini bisa juga terjadi dalam hal terdapat peraturan pelaksanaan yang dipandang tidak sesuai dengan dengan UU pokoknya;

5. Kurangnya sosialiasi peraturan perundang-undangan menimbulkan perbedaan persepsi dan pemahaman antara aparatur daerah dengan instansi Pemerintah;

6. Ketidaksiapan Pemerintah dalam menyediakan ketentuan mengenai norma, standar, prosedur, dan kriteria pelaksanaan suatu urusan pemerintahan tertentu dapat mendorong daerah mengambil inisiatif-inisitaf sendiri dengan membuat peraturan atau kebijakan yang dapat bertentangan dengan PP;

7. Pendelegasian pengaturan suatu hal tertentu dalam PUU kepada Perda yang tidak jelas terutama lingkup materi muatan yang diperintahkan untuk diatur Perda, dapat mempersulit daerah dalam menyusun Perda. Pendelegasian pengaturan kepada peraturan daerah yang tidak spesifik menyebut tingkatan Perda dapat berpotensi menimbulkan perselisihan kewenangan dan tumpang tindih pengaturan;

8. Koordinasi antara instansi Pemerintah dalam melakukan pembinaan dan pengawasan terhadap peraturan daerah kemungkinan belum sinergis dan terpadu.

Sebagai saran dalam rangka harmonisasi Perda dan PUU diharapkan Kementerian terkait yang diberi tugas menangani peraturan daerah agar segara mendesign program dan kegiatan bertahap dan terencana mulai dari kegiatan identifikasi permasalahan yang dihadapi masing-masing daerah, penentuan program penanganan, evaluasi dan monitoring perkembangan mengenai intensitas dan bobot penerapan di semua daerah.

Ruang Wilayah Kota Mataram merupakan pusat pemerintahan, pusat pendidikan, pusat perekonomian, serta pusat perdagangan barang dan jasa. Secara administratif Kota Mataram memiliki luas daratan 61,30 kilometer persegi dan 56,80 kilometer persegi perairan laut. Adapun Kota Mataram terbagi menjadi 5 Kecamatan, 50 Kelurahan berdasarkan Perda Kota Mataram Nomor 3 Tahun 2007 tentang Pemekaran Kecamatan dan Kelurahan di Kota Mataram. Bahwa dengan adanya 
Undang-Undang Nomor 26 Tahun 2007 tentang Penataan Ruang, Peraturan Pemerintah Nomor 26 Tahun 2008 tentang Rencana Tata Ruang Wilayah Nasional, dan Peraturan Daerah Provinsi Nusa Tenggara Barat Nomor 3 Tahun 2010 tentang Rencana Tata Ruang Wilayah Provinsi Nusa Tenggara Barat, maka kebijakan dan strategi pemanfaatan ruang wilayah nasional perlu dijabarkan ke dalam Rencana Tata Ruang Wilayah Kota Mataram. Atas dasar hal-hal tersebut di atas dan demi kepastian hukum, perlu ditetapkan Peraturan Daerah Kota Mataram tentang Rencana Tata Ruang Wilayah Kota Mataram.

Dengan diundangkan dan pemberlakuan Undang-Undang No 23 tahun 2014 tentang Pemerintahan Daerah maka Perda Kota Mataram No 12 Tahun 2011 tentang Rencana Tata Ruang Wilayah Kota Mataram sebagimana telah direvisi menjadi Perda RTRW Kota Mataram tahun 2011-2031 namun masih perlu diperhatikan apakah masih selaras dan sejalan dengan kemauan dari UU 23 tahun 2014 khusus bidang penataan ruang.

Terkait dengan pengelolaan sumber daya alam di laut, Perda RTRW Kota Mataram secara substansi terdapat perbedaan kewenangan dengan substansi yang tercantum dalam UU Pemda, yakni pada Pasal 11 ayat (2) huruf $m$ angka 5 Perda RT / RW yang menyebutkan bahwa : "Pemerintah Kota berwenang dalam mengembangkan budidaya perikananan air tawar, perikanan tangkap dan perikanan budidaya air laut". Hal tersebut berbeda setelah diberlakukannya UU No 23 tahun 2014 (UU Pemda) yang menyatakan bahwa pengelolaan budidaya air laut/kelautan adalah merupakan kewenangan Pemerintah provinsi. Hal ini sebagaimana dimuat pada beberapa pasal dalam UU Pemda sebagai berikut :

Pasal 14 ayat (1) menyatakan:

"Penyelenggaraan Urusan

Pemerintahan bidang kehutanan, kelautan serta energi dan sumber daya mineral dibagi antara Pemerintah Pusat dengan Pemerintah Provinsi”.

Pasal 27 menyatakan:

"Kewenangan daerah provinsi untuk mengelola sumber daya alam di laut sebagaimana dimaksud pada ayat (1) meliputi:

a. Eksplorasi, eksploitasi, konservasi, dan pengelolaan kekayaan laut di luar minyak dan gas bumi;

b. Pengaturan administratif;

c. Pengaturan tata ruang;

d. Ikut serta dalam memelihara keamanan di laut;

e. Ikut serta dalam mempertahankan kedaulatan negara."

Ayat (2) menyatakan"

"Kewenangan Daerah Provinsi untuk mengelola sumber daya alam di laut sebagaimana dimaksud pada ayat (1) meliputi:

a. Eksplorasi, eksploitasi, konservasi, dan pengelolaan kekayaan laut diluar minyak dan gas bumi;

b. Pengaturan administratif;

c. Pengaturan tata ruang;

d. Ikut serta dalam memilhara keamanan laut;

e. Ikut serta dalam mempertahankan kedaulatan negara."

Pasal 28 Ayat (1) menyatakan:

"Daerah Provinsi yang berciri kepulauan mempunyai kewenangan mengelola sumber daya alam di laut sebagaimana dimaksud dalam Pasal 27." 
Pasal 29 Ayat (1) menyatakan:

"Untuk mendukung penyelenggaraan pemerintahan di Daerah Provinsi yang berciri kepulauan, Pemerintah Pusat dalam menyusun perencanaan pembangunan dan menetapkan kebijakan DAU dan DAK harus memperhatikan Daerah Provinsi yang berciri kepulauan."

Dari uraian di atas, penulis dapat menyimpulkan bahwa terjadi insinkronisasi antara Pasal 11 ayat (2) huruf $\mathrm{m}$ angka 5 Perda RT / RW Kota Mataram dengan beberapa pasal dalam UU Pemda yang berkenaan dengan pengelolaan sumber daya alam di laut. Perda RT / RW Kota Mataram menyebutkan bahwa pengelolaan sumber daya alam di laut adalah merupakan kewenangan Pemerintah Kota yang merupakan bagian dari salah satu strategi pengembangan kawasan pertanian di Kota Mataram tentu hal ini tidak selaras dengan apa yang tertuang pada UU Pemda yang menyatakan bahwa pengelolaan sumber daya alam di laut merupakan kewenangan Pemerintah Provinsi sebagaimana yang sudah diuraikan pada pasal-pasal di atas. Tentu dengan adanya perbedaan kewenangan dalam aturan perundangundangan ini akan mengakibatkan terjadinya konflik kewenangan dalam pengelolaan sumber daya alam di laut yang akan dapat berdampak luas pada kepentingan daerah kota, provinsi ataupun secara nasional.

Sebagai solusi, persoalan ini tentu harus disikapi serius oleh Pemerintah Kota Mataram dan DPRD Kota Mataram dalam membuat peraturan yang selaras dan sesuai dengan peraturan perundang-undangan yang berlaku. Bisa juga hal ini mengacu pada asas perundang-perundangan, posisi seperti ini dapat menggunakan asas lex superior drogat legi inferiori, yakni peraturan perundang-undangan yang lebih tinggi mengesampingkan peraturan perundang-undangan yang lebih rendah. Dalam hal ini untuk patokan dalam hal kewenangan mengelola sumber daya alam di laut bisa mengacu pada Pasal 14 ayat (1), Pasal 27 ayat (1) dan (2), Pasal 28 dan Pasal 29 UU Pemda dengan mengesampingkan aturan yang termuat dalam Perda RT / RW Kota Mataram.

Dalam penggunaan asas lex superior drogat legi inferiori, ini sendiri terdapat pengecualian apabila substansi peraturan perundang-undangan lebih tinggi mengatur hal-hal yang oleh undang-undang ditetapkan menjadi wewenang peraturan perundang-undangan lebih rendah, artinya bisa saja kewenangan pengelolaan sumber daya alam di laut berpatokan pada Perda RTRW Provinsi Nusa Tenggara Barat, sepanjang hal-hal yang berkaitan dalam pengelolaan sumber daya alam di laut ini diatur dalam Perda RT / RW tersebut.

\section{PENUTUP}

Berdasarkan uraian yang telah dilakukan diatas maka dapat ditarik kesimpulan sebagai berikut :

1. Bahwa pengaturan tata ruang di Kota Mataram baik sebelum dan sesudah berlakunya UU No. 23 Tahun 2014 tentang Pemerintahan Daerah (UU Pemda) yakni mengacu pada Peraturan Daerah No. 12 Tahun 2011 tentang Rencana Tata Ruang Wilayah Kota Mataram (Perda RT / RW), namun pada pelaksanaannya terdapat pelanggaran-pelanggaran yang ditemukan sebagai contoh : 
pembangunan Rumah Makan AL Mahera dan Rumah Makan cepat saji KFC di jalan Langko Mataram. Hal ini disebabkan antara lain karena kurang masifnya sosialisasi terkait aturan, kebijakan, dan kewenangan yang ada pada Perda RTRW serta kurangnya kesadaran masyarakat akan arti pentingnya sebuah lingkungan yang aman, nyaman, dan ramah bagi warganya.

2. Bahwa terdapat insinkronisasi antara Perda No 12 Tahun 2011 tentang RT / RW Kota Mataram dengan UU No. 23 Tahun 2014 (UU Pemda) tentang Pemerintahan Daerah yakni pada Pasal 11 ayat 2 huruf $\mathrm{m}$ angka 5 Perda RT / RW dengan pasal 14 ayat (1), Pasal 27 ayat (1) dan (2), Pasal 28, Pasal 29 UU Pemda yang berkenaan dengan dengan Kewenangan Pemerintah Kota dan Pemerintah Provinsi dalam mengelola sumber daya alam di laut.

\section{DAFTAR PUSTAKA}

\section{Buku}

A. Muktie Fadjar, Tipe Negara Hukum, Malang: Bayumedia Publishing, 2003

Departemen Pekerjaan Umum, Pedoman Bahan Konstruksi Bangunan dan Rekayasa Sipil, Penyusunan Rencana Tata Ruang Wilayah Kota, Jakarta, 2009

Guritno Soejodibroto, Makalah: Tata Ruang Dalam Pembangunan Kota Yang Berkelanjutan, Jakarta: Asosiasi

DPRD Kota Seluruh Indonesia, 2009

Johnny Ibrahim, Teori Dan Metodologi

Penelitian Hukum Normatif, Malang:

Bayumedia Publishing, 2007
Jurnal dan Artikel

Arya Sosman, "Kajian Terhadap Perlindungan Dan Pengelolaan Lingkungan Hidup Dalam Tata Ruang Kota Mataram", Jurnal IUS Vol II Nomor 5 Universitas Islam Al-Azhar Mataram, Agustus 2014

A. Oka Mahendra, "Harmonisasi Peraturan Perundang-undangan", http://www. djpp.depkumham.go.id/htn-danpuu/421-harmonisasi-peraturanperundang-undangan.html diakses tanggal 27 Maret 2017

M. Saoki Oktava, "Eksistensi Ketetapan MPR Dalam Hirarki Peraturan PerUndang-Undangan Indonesia”, Jurnal IUS, Vol V. Nomor 1. April 2017

Sahrul Haidin, "Pelaksanaan Pengelolaan Keuangan Desa Setelah Berlakunya Undang-Undang Nomor 6 Tahun 2014 Tentang Desa (Studi Di Kabupaten Dompu)", Jurnal IUS, Vol V Nomor I, April 2017 